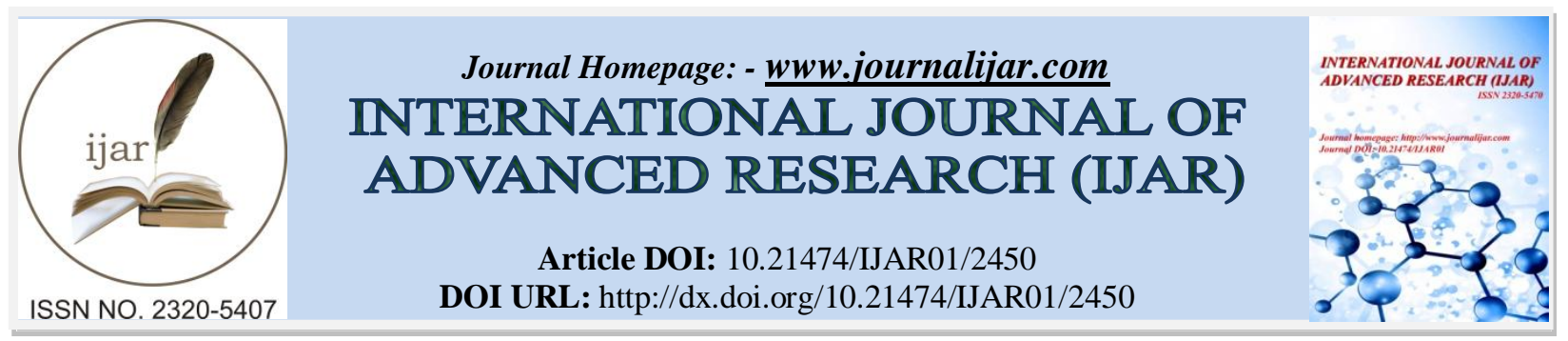

RESEARCH ARTICLE

\title{
ASSOCIATION OF VITAMIN D DEFICIENCY WITH HYPOTHYROIDISM IN NEPALESE POPULATION: A PILOT STUDY.
}

\author{
Mahesh Prakash Bhatta ${ }^{1,2}$, Bhupendra Raj Pandey ${ }^{3}$, Anupa Lamichhane ${ }^{4}$, Mahendra Prasad Bhatt ${ }^{2,4}$, \\ Mukund Joshi ${ }^{5}$, Alneil M. Hamza ${ }^{6}$ and Dipendra Raj Pandeya ${ }^{* 6,7}$. \\ 1. Department of Clinical Laboratory Sciences, Pokhara University, Pokhara, Nepal. \\ 2. LifeCare Diagnostics and Research Center Dhangadhi Pvt. Ltd, Dhangadhi, Nepal. \\ 3. United Reference Laboratory Pvt. Ltd. Pokhara, Nepal. \\ 4. Gandaki Medical College Teaching Hospital and Research Center Pvt. Ltd. Pokhara, Nepal. \\ 5. Seti Zonal Hospital, Dhangadhi, Nepal. \\ 6. Department of Clinical Laboratory Science, College of Applied Medical Sciences, Al Jouf University, Al \\ Qurayyat, Saudi Arabia. \\ 7. Department of Biochemistry, Nepalese Army Institute of Health Sciences, Kathmandu, Nepal
}

\section{Manuscript Info}

Manuscript History

Received: 20 October 2016

Final Accepted: 22 November 2016

Published: December 2016

Key words:-

Hypothyroidism, Vitamin D, Thyroid hormones

\section{Abstract}

Introduction: Vitamin D deficiency has shown a broad array of non skeletal diseases in recent years. It is supposed to be a key player in the pathogenesis of these metabolic diseases. Its deficiency has also been shown to be assorted with hypothyroidism with indecisive results. We therefore under took the present study to evaluate the association between vitamin D deficiencies in Hypothyroidism in a population of central Nepal.

Materials and methods: A total of 100 healthy individuals including 42 females and 58 males, where 100 hypothyroid patients including 20 males and 80 females were included in the study. Levels of Vitamin D, Thyroid function test (FT3, FT4, and TSH), Thyroperoxidase Antibody (Anti-TPO) was tested by electrochemiluminescence method and Calcium level was determined in accent 200 (PZ Cormay S.A, Poland), in Department of Immune serology and Biochemistry of United Reference Laboratory, Pokhara, Nepal. Statistical Analysis was done by Statistical Package for the Social Sciences (SPSS) Version 20.0.

Results: The mean age of the study subjects was $43 \pm 15$ years (range $18-83$ ) and $43 \pm 14$ (range 20-87) years for control group with no statistical significant difference, $\mathrm{P}=0.933$. The results of mean comparison of thyroid function tests and Vit.D between the two groups were found statistically significant different. The percentage of abnormal results comparison within study group for male and female was found to be statistically significant in only for TSH $(80 \%$ and $80 \%, \mathrm{P}=0.026$ ). Correlations between VitD and thyroid function test indicate that; for male there was a negative correlation of VitD with all thyroid functions tests, which was not statistically significant. For female the results indicate there was only a positive correlation

Corresponding Author:- Dr. Dipendra Raj Pandeya, PhD

Address:- Department of Clinical Laboratory Science, College of Applied Medical Sciences, Al Jouf University, Al Qurayyat, Saudi Arabia and Department of Biochemistry, Nepalese Army Institute of 
between (Vit. D level and FT4) which was statistically significant ( $\mathrm{r}$ $=0.226, \mathrm{n}=80, \mathrm{P}=0.044$ ).

Conclusion: The study indicates the Vitamin D deficiency is prevalent in hypothyroid patients, which suggests that they need routine testing and supplementation for the same.

Copy Right, IJAR, 2016,. All rights reserved.

\section{Introduction:-}

Vitamin D deficiency is a worldwide health problem (Edwards et al., 2014). Globally over billions of people are vitamin D insufficient [serum 25(OH)D3 of 10 to $24 \mathrm{ng} / \mathrm{ml}$ ] or deficient [serum 25(OH)D3 less than 10ng/ml] \} (Holick and Chen, 2008), which associates with the risk of chronic illnesses, including autoimmune, cardiovascular, and infectious diseases (Wilkinson et al., 2000; Ginanjar et al., 2006; Levin et al., 2007; Wang et al., 2008) . The prevalence of Vitamin D insufficiency in Nepalese adult is around 73.7\% (Bhatta et al., 2016). Hypothyroidism is a common disease in the society. Based on the effects of vitamin D on immune system, endocrine, autocrine, paracrine, regulation of gene expression, cell differentiation and proliferation the relationship between hypothyroidism and vitamin D gained importance.

The thyroid hormones often referred to as the major metabolic hormones; affect virtually every cell in the body. Hypothyroidism is define as deficiency of thyroid function, reduced production of FT3 and FT4 that lead to hyper secretion of pituitary hormone TSH (Kirsten, 2000). Thyroid disorder is defined as the abnormal thyroid stimulating hormones (TSH) with normal or abnormal thyroid hormones, free tri-iodothyronine (fT3) and free tetraiodothyronine(fT4) (Smyth, 2009). Thyroid disease is most common in general population and its prevalence has risen markedly in the last few decades affecting even younger age groups in the form of congenital hypothyroidism (Unnikrishnan et al., 2011). Thyroid disease is most common in general population and its prevalence increases with age. Globally, 300 million people are suffering from thyroid disorder. These disorders are 8 times more common in female than male (Sawin et al., 1985; Smyth, 2009). In Nepal, thyroid disorder is one of the major health problems with an average prevalence of about 30\% (Baral et al., 2002; Aryal et al., 2010; Chaudhari et al., 2012). Nepalese population is at higher risk for thyroid dysfunction due to geographical locations with high hilly areas with higher prevalence of iodine deficiency disorders (Baral et al., 1999; Baral et al., 2002; Gelal et al., 2009).

Vitamin D mediates its effect through binding to vitamin D receptor (VDR), and activation of VDR-responsive genes (Pike et al., 2010). Initially thought to be vitamin D just regulating calcium homeostasis, research has shown that this steroid hormone affects more than 36 cell types which possess VDR including thyroid gland; it also has a role in regulating cell proliferation and differentiation (Murray et al., 2012). Vitamin D exerts its metabolic effects on skeletal, cardiovascular and reproductive systems. So, a lower level of Vitamin D is likely to aggravate the systemic abnormalities associated with hypothyroidism (Wang et al., 2008; Chopra et al., 2011). Despite enough sunshine, this unexpected insufficiency of Vitamin D levels among Nepalese has become a matter of concern yet; no international health organization or governmental body has declared a health emergency to warn the public about the urgent need of achieving sufficient vitamin D blood levels (Naeem, 2010). It is still unclear if any association exists between hypothyroidism and Vitamin D insufficiency. The main aim of this study was to examine the relationship between hypothyroidism as well as autoimmune thyroid disorder with vitamin D deficiency and to justify the its association with serum calcium levels in a central Nepalese population.

\section{Materials and Methods:-}

This analytical study was conducted in the Department of Immune serology and Biochemistry of United Reference Laboratory Pvt. Ltd., Pokhara, Nepal during the period from October 2013 to June 2015. A total of two hundred subjects were included in this study after an informed consent. This study was approved by Research review committee (RRV).

Group I "control group": consisted of 100 apparently healthy individuals 42 Male (42\%) and 58 Female (58\%) of comparable age group (42.89 \pm 14.29$)$. None of them had any history of chronic medical diseases, intake of dietary supplements or thyroid disorder related drugs. They were not on vitamin D supplements. All subjects were following the same protocol. 
Group II "Study group": Formed by 100 patients, 20 Male (20\%) and 80 Female (80\%), their mean ages \pm S.D was $42.81 \pm 14.57$ year. They were diagnosed as hypothyroid patients if TSH level were higher than $4.20 \mu \mathrm{IU} / \mathrm{ml}$ with lower levels of FT3 than $3.1 \mathrm{pmol} / \mathrm{L}$ and FT4 than $12.0 \mathrm{pmol} / \mathrm{L}$. With no history of thyroxine and hypolipidemic drugs were included in the study. Patients with chronic renal failure, liver diseases, pregnancy and diabetes mellitus were excluded from the study.

\section{Laboratory measurements:-}

Venous blood sample was collected under sterile conditions in two different gel tubes for each subject with and without use of tourniquet. Serum was separated by the use of centrifuge, checked for hemolysis and if hemolyzed then that serum was discarded. Thyroid function test (FT3, FT4, and TSH), vitamin D [25(OH)D] and thyroperoxidase Antibody(Anti-TPO) was tested by electrochemiluminescence method (ECLIA) in Cobas e411 (Roche diagnostics, Germany).Calcium level was determined in accent 200 (PZ Cormay S.A, Poland).

\section{Statistical analysis:-}

The study data was analyzed by using SPSS program to compute descriptive parameters including mean and frequencies, and inferential statistics was used including student's $t$ test to test the significance of the differences between the mean values of two continuous variables and Chi-squire test $\left(\mathrm{X}^{2}\right)$ test the difference in proportions categorical variables between two groups. The level of confidence $(P<0.05)$ was considered as cutoff value for significance.

\section{Results:-}

Hypothyroid patients (study group) and normal individuals (Control group) were enrolled in this study. For each group 100 subject ( 20 male and 80 female) were selected. The mean age of the study subjects was $43 \pm 15$ years (range 18-83) and $43 \pm 14$ (range 20-87) years for control group with no statistical significant difference, $\mathrm{P}=0.933$. FT3, FT4, TSH, Anti TPO, Vit. D and calcium were studied to assess the association of hypothyroidism and vitamin $\mathrm{D}$ level in hypothyroid patients.

[Table1] shows the statistics of biochemical parameters computed for study and control groups which point out that results were found to be: FT3 $(4.8 \pm 1.2$ Vs $5.1 \pm 0.6, \mathrm{P}=0.011)$, FT4 $(13.7 \pm 3.9$ Vs $16.0 \pm 2.0, \mathrm{P}<0.001)$, TSH (15.5 \pm 21.5 Vs $2.5 \pm 1.1, \mathrm{P}<0.001)$, Anti TPO (104.5 \pm 183.8 Vs $36.6 \pm 108.2, \mathrm{P}=0.002)$, Vit. $\mathrm{D}(14.1 \pm 8.0$ Vs $20.1 \pm 9.6$, $\mathrm{P}<0.001)$ and calcium $(9.1 \pm 0.62 \mathrm{Vs} 9.1 \pm 0.75, \mathrm{P}=0.806)$.

Table 1:- Statistics of studied parameters in the study and control groups

\begin{tabular}{|c|c|c|c|}
\hline Parameters & Study group $(n=100)$ & Control group $(\mathrm{n}=100)$ & P-value \\
\hline \multicolumn{4}{|l|}{ Age, years } \\
\hline Means \pm SD & $43 \pm 15$ & $43 \pm 14$ & \multirow[t]{2}{*}{0.933} \\
\hline Range & $18-83$ & $20-87$ & \\
\hline \multicolumn{4}{|l|}{ FT3 } \\
\hline Means \pm SD & $4.8 \pm 1.2$ & $5.1 \pm 0.6$ & \multirow[t]{2}{*}{0.011} \\
\hline Range & $1.0-10.5$ & $3.5-6.6$ & \\
\hline \multicolumn{4}{|l|}{ FT4 } \\
\hline Means \pm SD & $13.7 \pm 3.9$ & $16.0 \pm 2.0$ & \multirow[t]{2}{*}{$<0.001$} \\
\hline Range & $1.4-24.6$ & $11.1-20.8$ & \\
\hline \multicolumn{4}{|l|}{$T S H$} \\
\hline Means \pm SD & $15.5 \pm 21.5$ & $2.5 \pm 1.1$ & \multirow[t]{2}{*}{$<0.001$} \\
\hline Range & $0.54-100.0$ & $0.37-4.9$ & \\
\hline \multicolumn{4}{|l|}{ AntiTPO } \\
\hline Means \pm SD & $104.5 \pm 183.8$ & $36.6 \pm 108.2$ & \multirow[t]{2}{*}{0.002} \\
\hline Range & $5.0-600.0$ & $5.0-600.0$ & \\
\hline \multicolumn{4}{|l|}{ VitD } \\
\hline Means \pm SD & $14.1 \pm 8.0$ & $20.1 \pm 9.6$ & \multirow[t]{2}{*}{$<0.001$} \\
\hline Range & $3.0-33.0$ & $3.3-50.0$ & \\
\hline \multicolumn{4}{|l|}{ Calcium } \\
\hline Means \pm SD & $9.1 \pm 0.62$ & $9.1 \pm 0.75$ & \multirow[t]{2}{*}{0.806} \\
\hline Range & $8.1-12.4$ & $5.1-11.2$ & \\
\hline$P$ value based on Stud & ignificant at $(p<0.05)$ & & \\
\hline
\end{tabular}


[Table 2] shows comparison of studied parameters between gender types within study group. The results indicate that male and female mean age was $(42 \pm 12,43 \pm 15, \mathrm{P}=0.806)$ with no statistical significance difference. In addition, the results of studied biochemical parameter were compared between male and female which found to be FT3 (5.3 \pm 0.82 Vs $4.7 \pm 1.2, \mathrm{P}=0.010)$, FT4 (14.9 \pm 3.0 Vs 13.4 $\pm 4.1, \mathrm{P}=0.077)$, TSH (11.1 \pm 11.0 Vs $16.6 \pm 23.3, \mathrm{P}=0.125$ ), Anti TPO (46.6 \pm 132.1 Vs $118.9 \pm 192.6, \mathrm{P}=0.118)$, Vit. D (14.4 \pm 8.3 Vs $14.0 \pm 8.1, \mathrm{P}=0.863)$ and calcium $(9.2 \pm 0.61$ Vs $9.1 \pm 0.62, \mathrm{P}=0.678$ ) respectively, with statistical significant difference in FT3 comparison result.

Table 2:- Comparison of studied parameters between gender types within study group

\begin{tabular}{|c|c|c|c|}
\hline Parameters & Male $(n=20)$ & $\operatorname{Female}(\mathrm{n}=80)$ & P-value \\
\hline \multicolumn{4}{|l|}{ Age, years } \\
\hline Means \pm SD & $42 \pm 12$ & $43 \pm 15$ & \multirow[t]{2}{*}{0.809} \\
\hline Range & $27-72$ & $18-83$ & \\
\hline \multicolumn{4}{|l|}{ FT3 } \\
\hline Means \pm SD & $5.3 \pm 0.82$ & $4.7 \pm 1.2$ & \multirow[t]{2}{*}{0.010} \\
\hline Range & $3.4-7.0$ & $1.0-10.5$ & \\
\hline \multicolumn{4}{|l|}{ FT4 } \\
\hline Means \pm SD & $14.9 \pm 3.0$ & $13.4 \pm 4.1$ & \multirow[t]{2}{*}{0.077} \\
\hline Range & $10.1-19.6$ & $1.4-24.6$ & \\
\hline \multicolumn{4}{|l|}{$T S H$} \\
\hline Means \pm SD & $11.1 \pm 11.0$ & $16.6 \pm 23.3$ & \multirow[t]{2}{*}{0.125} \\
\hline Range & $0.54-47.3$ & $1.3-100.0$ & \\
\hline \multicolumn{4}{|l|}{ AntiTPO } \\
\hline Means \pm SD & $46.6 \pm 132.1$ & $118.9 \pm 192.6$ & \multirow[t]{2}{*}{0.118} \\
\hline Range & $5.0-600.0$ & $5.0-600.0$ & \\
\hline \multicolumn{4}{|l|}{ VitD } \\
\hline Means \pm SD & $14.4 \pm 8.3$ & $14.0 \pm 8.1$ & \multirow[t]{2}{*}{0.863} \\
\hline Range & $3.2-29.8$ & $3.0-33.0$ & \\
\hline \multicolumn{4}{|l|}{ Calcium } \\
\hline Means \pm SD & $9.2 \pm 0.61$ & $9.1 \pm 0.62$ & \multirow[t]{2}{*}{0.678} \\
\hline Range & $8.1-10.1$ & $8.1-12.4$ & \\
\hline
\end{tabular}

[Table 3] shows that percentage of abnormal result within study group for male and female was found to be FT3 ( $0 \%$ and $10 \%, \mathrm{P}=0.140)$, FT4 (25\% and $15 \%, \mathrm{P}=0.268)$, TSH $(80 \%$ and $80 \%, \mathrm{P}=0.026)$, Anti TPO (15\% and $33 \%$, $\mathrm{P}=0.122)$, Vit. $\mathrm{D}(90 \%$ and $89 \%, \mathrm{P}=0.873)$ and calcium $(10 \%$ and $11 \%, \mathrm{P}=0.873)$ respectively, with statistical significant difference in TSH comparison result. Association of abnormal result with hypothyroid patients' gender depicted in [Figure1].

Table 3:- Percentage of abnormal parameters values and association with gender within study group

\begin{tabular}{|l|c|c|c|c|c|c|}
\hline \multirow{2}{*}{ Parameters } & \multicolumn{2}{|c|}{ Male $(\mathrm{n}=20)$} & \multicolumn{2}{c|}{ Female $(\mathrm{n}=80)$} & \multirow{2}{*}{ P2 2 value } \\
\cline { 2 - 5 } & Normal & Abnormal & Normal & Abnormal & & \\
\hline FT3 & 20 & $0(0 \%)$ & 72 & $8(10 \%)$ & 2.17 & 0.140 \\
\hline FT4 & 15 & $5(25 \%)$ & 68 & $12(15 \%)$ & 1.13 & 0.268 \\
\hline TSH & 4 & $16(80 \%)$ & 4 & $76(80 \%)$ & 4.89 & 0.026 \\
\hline AntiTPO & 17 & $3(15 \%)$ & 54 & $26(33 \%)$ & 2.37 & 0.122 \\
\hline VitD & 2 & $18(90 \%)$ & 9 & $71(89 \%)$ & 0.025 & 0.873 \\
\hline Calcium & 18 & $2(10 \%)$ & 71 & $9(11 \%)$ & 0.025 & 0.873 \\
\hline
\end{tabular}

$P$ value based on Student's t-test: significant at $(p<0.05)$ 


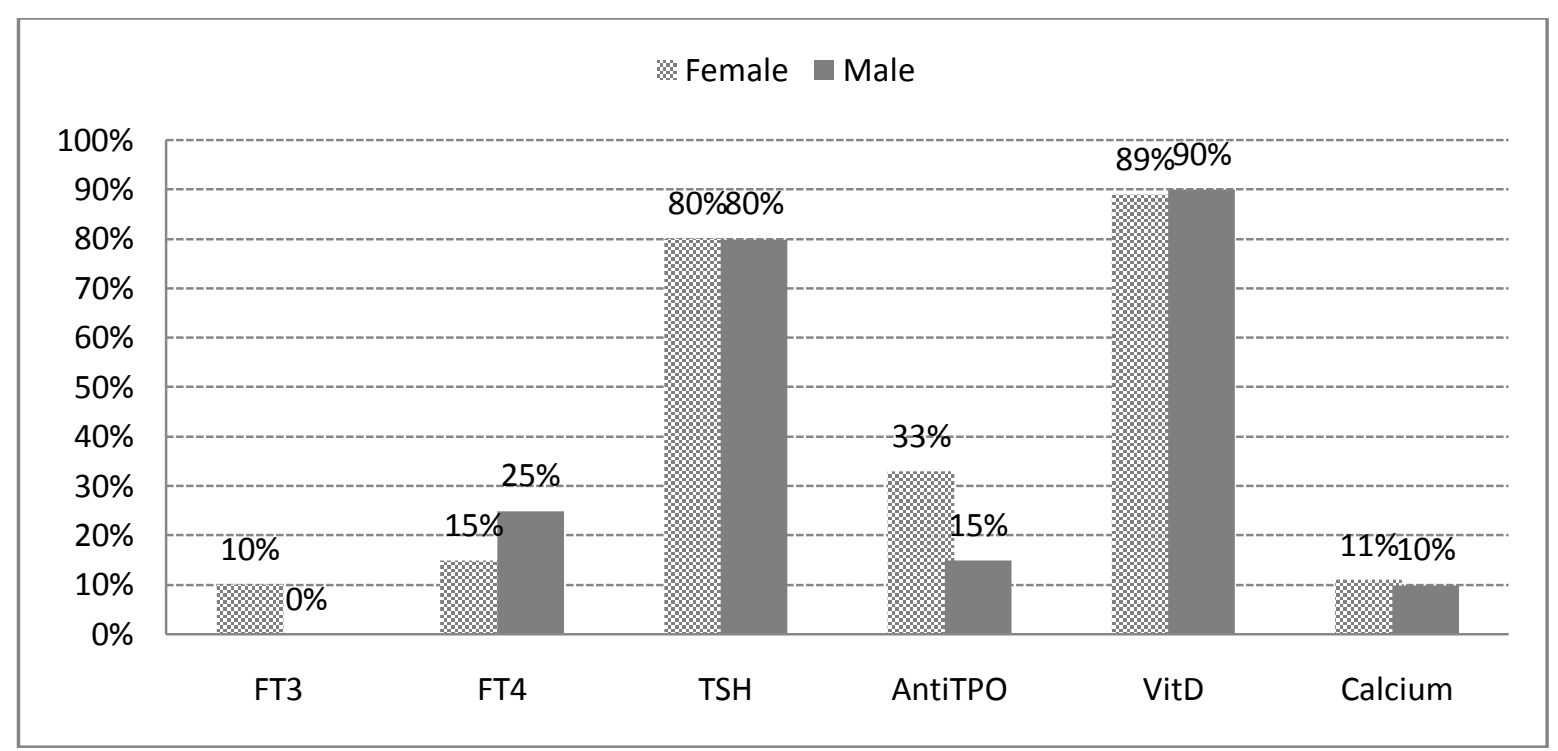

Figure1: Association of abnormal result with hypothyroid patients' gender

[Table 4] show the correlation that was run to determine the relationship between FT3, FT4, TSH, Anti TPO and Vit. D within study group gender type. For male the result indicates there was a negative correlation with all thyroid functions parameter, which was not statistically significant as an example the correlation between Vit. D and TSH was depicted in [Figure 2].

Table 4:- Correlation of VitD level with thyroid function tests within study group

\begin{tabular}{|c|c|c|c|c|}
\hline \multirow{2}{*}{ TFTs } & \multicolumn{2}{|c|}{ Male $(\mathrm{n}=20)$} & \multicolumn{2}{c|}{ Female(n=80) } \\
\cline { 2 - 5 } & Person $\mathrm{r}$ & P- value & $\mathrm{r}$ & P-value \\
\hline FT3 & -0.014 & 0.952 & -0.046 & 0.682 \\
\hline FT4 & -0.02 & 0.934 & 0.226 & 0.044 \\
\hline TSH & -0.41 & 0.072 & -0.219 & 0.051 \\
\hline AntiTPO & -0.014 & 0.952 & -0.126 & 0.267 \\
\hline
\end{tabular}

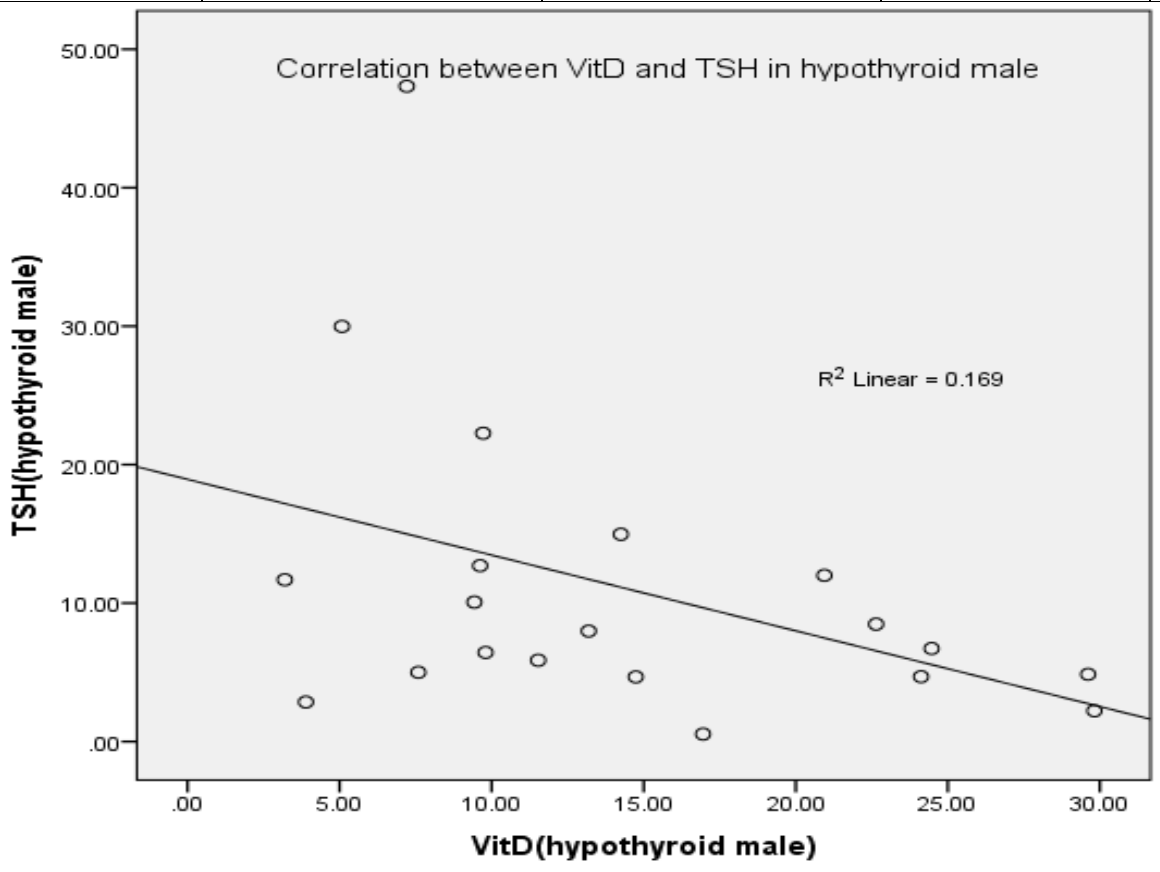

Figure 2:- Correlation between TSH and VitD in hypothyroid male 
For female the result indicates there was only a positive correlation between (Vit. D level and FT4) which was statistically significant $(r=-0.226, n=80, p=0.044)$. As example the correlation between (Vit D and TSH), (Vit D level and FT4) were depicted in [Figure 3] and [Figure 4] respectively.

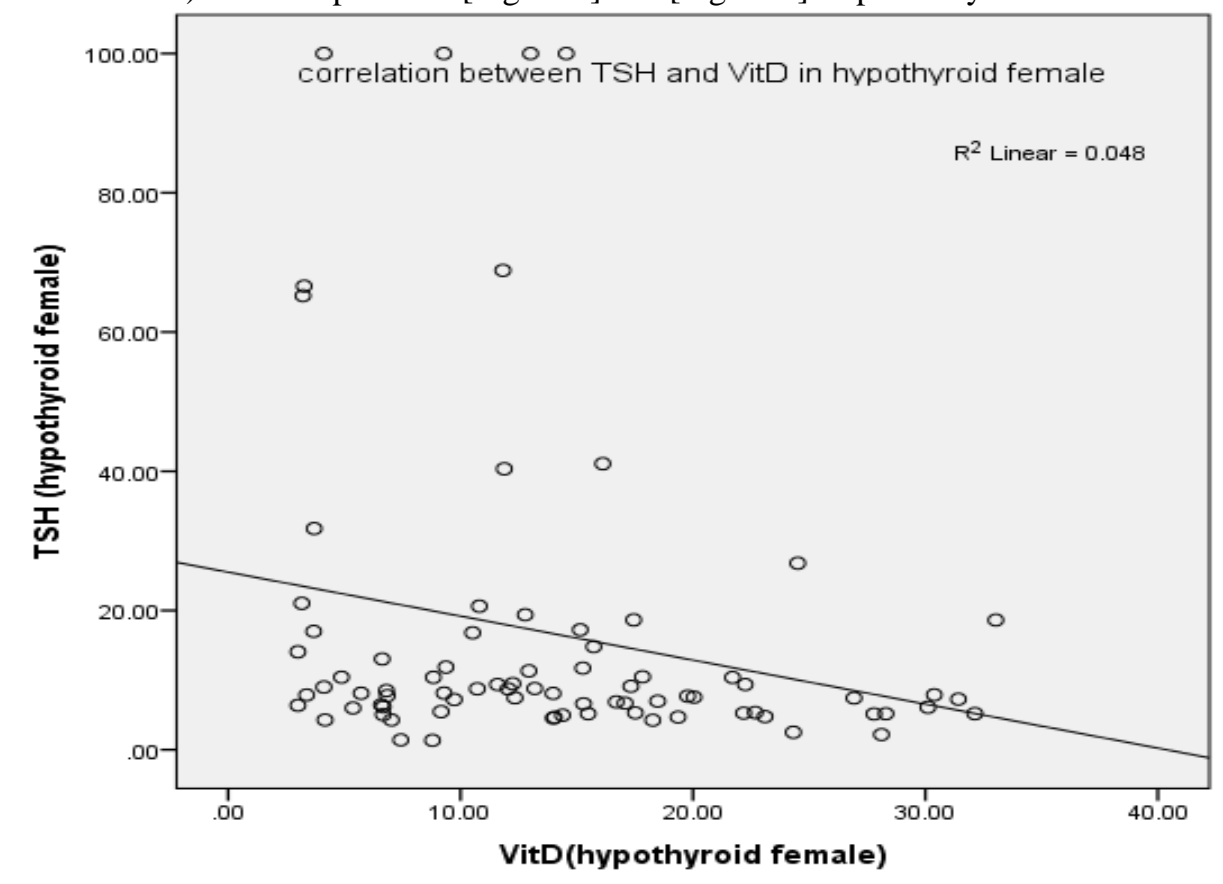

Figure 3:- Correlation between TSH and VitD in hypothyroid female

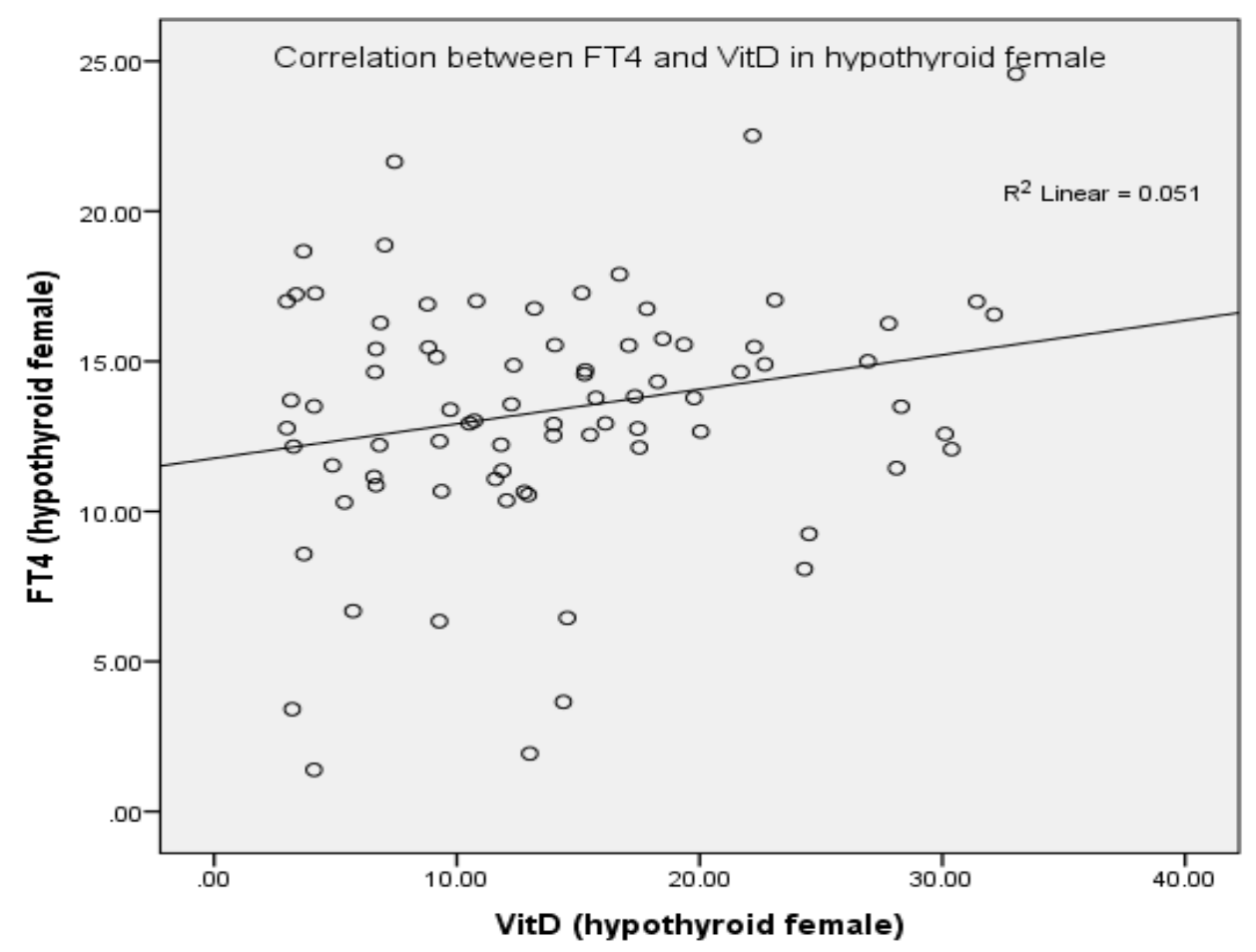

Figure 4:- Correlation between FT4 and Vit D in hypothyroid female 


\section{Discussion:-}

Vitamin D is known for its primary role in bone and mineral homeostasis, and it has been shown recently that its deficiency is associated with various diseases such as cardiovascular disease, cancer, infection, diabetes and other chronic diseases (Holick, 2004; Andress, 2006; Bikle, 2008). Interestingly, it has been shown recently that vitamin $\mathrm{D}$ has potent immunomodulatory effects and plays important roles in the pathogenesis of autoimmune diseases (Vondra et al., 2015). Few studies have been conducted in order to find any significant association between the levels of vitamin D and hypothyroidism and to determine whether vitamin D deficiency involves in the pathogenesis of hypothyroidism or rather a consequence of the disease and those that yielded conflicting results.

To our knowledge, there are some researchers examined the prevalence of Vitamin D deficiency in Nepalese populations but our study was one from few studies aimed to examine the association of Vitamin D level with hypothyroidism in Nepal mainly Mid western region. We therefore undertook this study to evaluate the levels of vitamin D among patients with hypothyroidism compared to healthy controls who did not complain from hypothyroidism or any thyroid diseases.

Low levels of $25(\mathrm{OH})$ Vitamin D is now a commonly accepted finding in central Nepalese population and overt deficiency has often been associated with a number of clinical disorders. We observed in this study that vitamin D does have a role to play in hypothyroidism, hypothyroid patients had significantly lower levels of serum $25(\mathrm{OH})$ Vitamin D as compared to controls ( $\mathrm{p}<0.001$ ). This outcome was supported by Tahir et al. (Tahir et al., 2016) studied that illustrated deficiency of serum Vit D levels were significantly associated with degree and severity of hypothyroidism, conducted in Indian population. In support to our study, Richards study also reported that low thyroid hormones lead to a lack of Vitamin D (Richards, 2008). Few study conducted by Ma et al. (Ma et al., 2015), Sayki et al. (Sayki et al., 2015) and Unal et al. (Unal et al., 2014) in autoimmune thyroiditis also has harmony with our study that Vitamin D deficiency is correlated with thyroid disorder. In this study, no significant different between calcium level was found ( $\mathrm{P}=0.806)$, supported by Al-hakeim et al. (Al-Hakeim et al., 2009) who illustrated changes in ionizes $\mathrm{Ca}$, but not total $\mathrm{Ca}$, means that the physiologically active form of $\mathrm{Ca}$ is affected, while the overall concentration of $\mathrm{Ca}$ is still significantly unchanged. This Study reveal; significant difference in Anti TPO level between two groups, significantly higher is study group than in control group $(\mathrm{P}=0.002)$.

In our study, it is found that female had low vitamin D and calcium level while had high Anti-TPO and TSH level than male, but were not significantly correlated. While Gannagé-Yared et al., (Gannagé-Yared et al., 2000), Roomi et al., (Roomi et al., 2015), Verdoia et al., (Verdoia et al., 2015), and Bolland et al. (Bolland et al., 2007) has reported significantly higher serum level of $25(\mathrm{OH}) \mathrm{D}$ in Healthy male than in female. Furthermore, Elsammak et al., (Elsammak et al., 2011), and Lippi et al. (Lippi et al., 2012) study revealed serum 25 (OH) D levels did not significantly differ between male and female. Differences in the dietary intake of vitamin D, selection of patients, seasonal variations and exposure to sunlight can be explained the discrepancies between these studies.

We observed a negative correlation of serum $25(\mathrm{OH})$ Vitamin D levels with TSH in both male and female hypothyroid patients on Pearson's correlation analysis $(r=-0.41, \mathrm{P}=0.072$ and $\mathrm{r}=-0.219, \mathrm{P}=0.051)$, suggesting an inter relationship that exists between vitamin $\mathrm{D}$ insufficiency and hypothyroidism. It also states a putative role of vitamin D as a potential modifiable risk factor for hypothyroidism. In order to function, vitamin D must bind to its receptor VDR which is found in several cell types including thyroid gland (Norman, 2008). Studies have shown that patients of autoimmune thyroid disease have several VDR polymorphisms that affect its expression and activation (Zaletel and Gaberscek, 2011). Probably vitamin D plays a role in maintaining a euthyroid state by interacting with its receptor in the thyroid gland. We also observed negative correlation between vitamin D and anti TPO level in both gender ( $\mathrm{r}=-0.014, \mathrm{P}=0.952$, in male and $\mathrm{r}=-0.126, \mathrm{P}=0.267$, In female), which means that anti-TPO thyroid antibodies tended to be higher with lower serum $25(\mathrm{OH}) \mathrm{D}$ levels. Which was similar to the studies carried by Unal et al. (Unal et al., 2014) and Mazokopakis et al. (Mazokopakis et al., 2015) but those studies found significant correlation $(\mathrm{r}=-0.176, \mathrm{p}=0.003$ and $\mathrm{r}=-0.43, \mathrm{P}<0.00001)$ between Vitamin $\mathrm{D}$ and Anti TPO. Our study showed the positive correlation between FT4 and Vitamin D in female $(r=0.226, p=0.044, P<0.05)$,

One of the earlier studies reported low vitamin D level in both hypothyroid and hyper thyroid postmenopausal women (Clements et al., 2008). However, in the present study, positive correlation between FT4 and vitamin D3 was statistically significant in females probably due to low mean vitamin D values observed in females. Goswami et al. (Goswami et al., 1998) have also reported similar result in hyperthyroidism patients. According to this study significant number of patients $(46 \%)$ with hyperthyroidism in India had fat malabsorption. Absorption of fat soluble 
vitamins such as vitamin D is likely to be impeded in such a state. However, due to less sample size in male there was no significant correlation noticed.

In study group, only $8 \%$ had abnormal FT3 level ( $0 \%$ in male and $10 \%$ in female; $\mathrm{P}=0.140)$ and $17 \%$ had abnormal FT4 level (25\% in male and $15 \%$ in female; $\mathrm{P}=0.268)$, Furthermore $92 \%$ had abnormal TSH level $(80 \%$ in both male and female; $\mathrm{P}=0.026$ ).

\section{Conclusion:-}

Study indicated that patients with hypothyroidism suffered from hypovitaminosis D which encourages the supplementation of Vitamin D in hypothyroid patients and screening of Vitamin D levels in hypothyroid patients. Further, large scale prospective studies will be required to establish a cause and effect relation of vitamin D deficiency in pathogenesis of hypothyroidism.

\section{Disclosure:-}

The authors declared no conflicts of interest.

\section{Acknowledgements:-}

We would like to thank entire team of URL for their unlimited support without which this work would not have been completed.

\section{References:-}

1. Edwards, M., Cole, Z., Harvey, N. and Cooper, C. (2014): The global epidemiology of vitamin d status. J Aging Res Clin Practice., 3, 148-158.

2. Holick, M.F. and Chen, T.C. (2008): Vitamin D deficiency: a worldwide problem with health consequences. Am J Clin Nutr., 87(4):1080-6.

3. Wang, T.J., Pencina, M.J., Booth, S.L., Jacques, P.F., Ingelsson, E., Lanier, K., Benjamin, E.J., D’Agostino, R.B., Wolf, M. and Vasan, R.S. (2008): Vitamin D deficiency and risk of cardiovascular disease. Circulation. 117(4):50311 .

4. Ginanjar, E., Setiati, S. and Setiyohadi, B. (2006): Vitamin D and autoimmune disease. Acta Med Indones., 39(3):133-41.

5. Wilkinson, R.J., Llewelyn, M., Toossi, Z., Patel, P., Pasvol, G., Lalvani, A., Wright, D., Latif, M. and Davidson, R.N. (2000): Influence of vitamin D deficiency and vitamin D receptor polymorphisms on tuberculosis among Gujarati Asians in west London: a case-control study. The Lancet., 355(9204):618-21.

6. Levin, A., Bakris, G., Molitch, M., Smulders, M., Tian, J., Williams, L. and Andress, D. (2007): Prevalence of abnormal serum vitamin D, PTH, calcium, and phosphorus in patients with chronic kidney disease: results of the study to evaluate early kidney disease. Kidney Int., 71(1):31-8.

7. Bhatta, M.P., Pandey, B.R., Gurung, K.M., Nakarmi, R., Gurung, K., Gurung, L.B. and Magar, S.R. (2016): Prevalence of vitamin D deficiency among adult population of Western Region of Nepal. Int J Med Biomed Sci., 1(2):7-12.

8. Kirsten, D. (2000): The thyroid gland: physiology and pathophysiology. Neonatal Netw., 19(8):11-26.

9. Smyth, P. (2009): Epidemiology of Thyroid Dysfunction - Hypothyroidism and Hyperthyroidism. Darmstadt, Germany.

10. Unnikrishnan, G.A. and Usha, M.V. (2011): Thyroid disorders in India:An epidemiological perspective. Indian J Endcrinol Metab., 15(2):78-81.

11. Sawin, C.T., Castelli, W.P., Hershman, J.M., McNamara, P. and Bacharach, P. (1985): The aging thyroid: thyroid deficiency in the Framingham study. Arch Intern Med., 145, 1386-8.

12. Baral, N., Lamsal, M., Koner, B. and Koirala, S. (2002): Thyroid dysfunction in eastern Nepal. Southeast Asian J Trop Med Public Health., 33(3):638-41.

13. Chaudhari, R.K., Gelal, B., Brodie, D. and Baral, N. (2012): Thyroid function \& urinary iodine status in primary school age children of the hills \& plains of Eastern Nepal. Indian Pediatr.,49, 332-3.

14. Aryal, M., Gyawali, P., Rajbhandari, N., Aryal, P. and Pandeya, D.R. (2010): A prevalence of thyroid dysfunction in Kathmandu University Hospital, Nepal. Biomed Res., 21(21):411-5..

15. Gelal, B., Aryal, M., Lal, D. B., Bhatta, B., Lamsal, M. and Baral, N. (2009): Assessment of iodine nutrition status among school age children of Nepal by urinary iodine assay. Southeast Asian J Trop Med Public Health., 40(3):53843.

16. Baral, N., Ramaprasad, C., Lamsal, M., Koner, B. and Koirala, S. (1999): Assay of iodine deficiency status in three ecological regions of Nepal by a microdigestion method. Southeast Asian J Trop Med Public Health., 30, 527-31. 
17. Pike, J.W. and Meyer, M.B. (2010): The Vitamin D Receptor: New Paradigms for the Regulation of Gene Expression by 1,25-Dihydroxyvitamin $\mathrm{D}_{3}$. Endocrinol Metab Clin North Am., 39, 255-69.

18. Murray, R.K., Bender, D.A., Botham, K.M., Kennely, P.J., Rodwell, V.W. and Weil, P.A. (2012): Micronutrients: Vitamins and Minerals- Harper's Illustrated Biochemistry. 29th Edition ed., p. 529-31.

19. Chopra, S., Cherian, D. and Jacob, J.J. (2011): The thyroid hormone, parathyroid hormone and vitamin D associated hypertension. Indian J Endocrinol Metab.,15, 354-60.

20. Naeem, Z. (2010): Vitamin D Deficiency- An Ignored Epidemic. Int J Health Sci., 4(1):5-6.

21. Bikle, D.D. (2008): Vitamin D and the immune system: role in protection against bacterial infection. Curr Opin Nephrol Hypertens., 17(4):348-52.

22. Holick, M.F. (2004): Vitamin D: importance in the prevention of cancers, type 1 diabetes, heart disease, and osteoporosis. Am J Clin Nutr., 79(3):362-71.

23. Andress, D. (2006): Vitamin D in chronic kidney disease: a systemic role for selective vitamin D receptor activation. Kidney Int., (1):33-43.

24. Vondra, K., Stárka, L. and Hampl, R. (1015): Vitamin D and Thyroid Diseases. Physiol Res., 64(2):95-100.

25. Tahir, G.A., Afzal, T.M., Garg, N. (2016): Association of Vitamin D3 and Serum Calcium Levels in Subclinical Hypothyroidism. Indian J Appl Res., 6(7):309-10.

26. Richards, B. (2008): Low Vitamin D Contributes to Thyroid Problems. Health News.

27. Ma J, Wu D, Li C, Fan C, Chao N, Liu J, Li Y, Wang R, Miao W, Guan H.

28. Ma, J., Wu, D., Li, C., Fan, C., Chao, N., Liu, J., Li, Y., Wang, R., Miao, W., and Guan, H. (2015): Lower serum 25hydroxyvitamin D level is associated with 3 types of autoimmune thyroid diseases. Medicine. $94,39$.

29. Sayki, A.M., Topaloglu, O., Ucan, B., Karakose, M., Karbek, B., Tutal, E., Caliskan, M., Ginis, Z., Cakal, E. and Sahin, M. (2015): Isolated vitamin D deficiency is not associated with nonthyroidal illness syndrome, but with thyroid autoimmunity. Scientific World J., Volume 2015, Article ID 239815

30. Unal, A.D., Tarcin, O., Parildar, H., Cigerli, O., Eroglu, H. and Demirag, N.G. (2014): Vitamin D deficiency is related to thyroid antibodies in autoimmune thyroiditis. Centr Eur J Immunol. 39(4):493-97.

31. Al-Hakeim, H.K. (2009): Serum levels of lipids, calcium and magnesium in women with hypothyroidism and cardiovascular diseases. J Lab Physicians., 1(2):49-52.

32. Gannagé-Yared, M.H., Chemali, R., Yaacoub, N. and Halaby, G. (2000): Hypovitaminosis D in a sunny country: relation to lifestyle and bone markers. J Bone Miner Res., 15(9):1856-62.

33. Roomi, M.A., Farooq, A., Ullah, E. and Lone, K.P. (2015): Hypovitaminosis D and its association with lifestyle factors. Pak J Med Sci., 31(5):1236.

34. Verdoia, M., Schaffer, A., Barbieri, L., Di Giovine, G., Marino, P., Suryapranata, H., De Luca, G. and Group N.A.S. (2015): Impact of gender difference on vitamin D status and its relationship with the extent of coronary artery disease. Nutr Metab Cardiovasc Dis., 25, 464-70.

35. Bolland MJ, Grey AB, Ames RW, Horne AM, Mason BH, Wattie DJ, Gamble GD, Bouillon R, Reid IR.

36. Bolland, M.J., Grey, A.B., Ames, R.W., Horne, A.M., Mason, B.H., Wattie, D.J., Gamble, G.D., Bouillon, R. and Reid, I.R. (2007): Age-, gender-, and weight-related effects on levels of 25-hydroxyvitamin D are not mediated by vitamin D binding protein. Clin Endocrinol (Oxf)., 67(2):259-64.

37. Elsammak, M., Al-Wossaibi, A., Al-Howeish, A. and Alsaeed, J. (2011): High prevalence of vitamin D deficiency in the sunny Eastern region of Saudi Arabia: a hospital-based study. East Mediterr Health J., 17(4):317.

38. Lippi, G., Montagnana, M., Meschi, T. and Borghi, L. (2012): Vitamin D concentration and deficiency across different ages and genders. Aging Clin Exp Res., 24(5):548-51.

39. Norman, A.W. (2008): From vitamin D to hormone D: fundamentals of the vitamin D endocrine system essential for good health. Am J Clin Nutr.,88(2):491-9.

40. Zaletel, K. and Gaberscek, S.(2011): Hashimoto's thyroiditis: from genes to the disease. Curr Genomics., 12(8):57688.

41. Mazokopakis, E.E., Papadomanolaki, M.G., Tsekouras, K.C., Evangelopoulos, A.D., Kotsiris, D. and Tzortzinis, A.A. (2015): Is vitamin D related to pathogenesis and treatment of Hashimoto's thyroiditis? Hell J Nucl Med., 18, 222-7.

42. Clements, M.R., Davies. M., Hayes. M.E., Hickey. C.D., Lunb. G.A. and Mawer, E.B. (2008): Plasma 1,25(OH)2D levels decrease in postmenopausal women with hypovitaminosis D. Eur J Endocrinol., 158, 571-6.

43. 41.Goswami, R., Tandon, R.K., Dudha, A., Kochupillai, N. (1998): Prevalence and significance of steatorrhea in patients with active Graves' disease. Am J Gastroenterol., 93, 1122-5. 